УДК 32.019(325);7.091

DOI https://doi.org/10.32837/apfs.v0i29.968

Л. В. Харченко

ORCID ID: https://orcid.org/0000-0002-0009-9472

доктор політичних наук,

доцент кафедри міжнародних відносин та суспільних наук Національного університету біоресурсів і природокористування України

\title{
ВАЖЛИВІСТЬ ВІДОБРАЖЕННЯ КОНФЛІКТУ НА СХОДІ УКРАЇНИ В СУЧАСНІЙ УКРАЇНСЬКІЙ ДРАМАТУРГІЇ: НАЦІОНАЛЬНИЙ І ЛОКАЛЬНИЙ РІВЕНЬ УСВІДОМЛЕННЯ ПРОБЛЕМИ
}

Від початку військового протистояння на Сході України (з квітня 2014 року) в українському науковому просторі не з'явилося жодної праці, яка б мала на меті дослідити й проаналізувати українські драматургічні тексти, присвячені зазначеному конфлікту, а також обгрунтувати важливість їх звучання для глядацької аудиторії з боку об’єднувального чинника у сфері подолання актуалізації факторів «іншування» та «відторгнення» . Серед сучасних українських авторів, які вивчали важливість документального театру в соціокультурному контексті, слід відзначити О.А. Апчел [1-3] та М.А. Гоманюка [4-6], щоправда, предметом дослідження зазначених науковців не виокремлювався військовий конфлікт у драматургічному тексті, а значною мірою приділялася увага документалізації поточних подій та актуальних соціальних проблем у формі документального театрального мистецтва.

3 огляду на перебування частин України в зоні різних цивілізаційних впливів, зумовлених у тому числі військовим протистоянням на Сході України, можемо констатувати глибокий конфлікт і «зіткнення» ідентичностей із кардинально протилежними точками зору на перебіг і кінцевий результат війни. У такому плані роль культури суспільства, як на загальному, так і на індивідуальному рівні видається надзвичайно важливою, оскільки карбування «нормальності» вбивств як на війні, так і в мирний час за національними, релігійними й іншими принципами може спричинити незворотні ментальні трансформації. 3 огляду на наведені вище загрози й ризики вважаємо науковий пошук у такому напрямі надзвичайно актуальним і потрібним.

Починаючи з 1991 року, державна стратегія формування національної ідеї була спрямована на пошук спільних єднальних моментів (соборність, примирення тощо) в колективних ідентичностях розрізненого поля української нації. Планувалося, що така ідея, підкріплена сучасними комунікативними технологіями, стане рушійною силою в становленні громадянського суспільства, здатного побудувати міцний стрижень для сильної держави. Проте на заваді стало протилежне гео- політичне тяжіння окремих регіонів України, й запропоновані ідеї відбулися лише як символічні замінники, напівфабрикати, які лише посилили напругу в суспільстві. Засоби масової інформації, які мали надзвичайний вплив у 90 роках минулого й 10 -х роках нового століття, після Революції Гідності втратили рівень довіри й, відповідно, свій вплив на формування суспільної думки. Перехідний період становлення державності перейшов у перманентний стан, тому смисли, які вкладалися в пошук національної ідеї, набули мінливості й фрагментарності й забезпечували лише поточний момент політичної ситуації.

Культура й мистецтво завжди були тісно пов'язані з розвитком суспільства, який передбачає політичну складову частину. Проте сучасний світ, який характеризується насамперед непередбачуваністю та неможливістю логічно пояснити ті чи інші вектори розвитку суспільно-політичної парадигми, ставить перед культурою та мистецтвом нові вимоги, які навряд чи вписуються в попередню модель культури в цілому. Якщо раніше можна було стверджувати, що «ідеологічний потенціал культури сприймається не ізольовано від середовища, а в єдиному контексті з ним, в органічному взаємозв'язку з тим тлом (політичним, ідеологічним, культурним, історичним, психологічним і так далі), на якому встановлюється контакт, відбувається взаємодія людини й культури» [7, с. 112], нині ми можемо спостерігати певний феномен формування уявлень, цінностей, прагнень та ідеалів індивіда незалежно від запропонованої ідеологічної парадигми, наявної в суспільстві. Науково-технічна революція змінила обличчя культури нашого суспільства, спричинила злам усталених стереотипів, переоцінку цінностей, брак визначених моральних взірців в усіх сферах суспільного життя. Коли система цінностей перебуває в стані трансформації, виникає глобальна проблема втрати людської індивідуальності, яка може загубитися в умовах багатства можливостей. У такій ситуації, як слушно зауважує Ю.А. Семенова, «головною небезпекою стає «конфуз ідентичності», який проявляється в кінцевому мораторії, пов'язаному з випадковим 
вибором. Гра з історичними можливостями обертається ланкою безповоротних митей, які визначають історичне буття індивіда» [8, с. 97].

Важливу роль, на нашу думку, в запобіганні зазначених вище ментальних загроз могли б відігравати такі форми мистецтва, як кіно й театр. Було б несправедливо відзначати, що в такому напрямі не ведеться робота, в тому числі на державному рівні. Протягом останніх років виділяються кошти на створення художніх і документальних фільмів, що спрямовані на донесення до громадян України простою для сприйняття кінематографічною формою перебігу подій на Сході. Найвдалішими спробами були художні фільми «Кіборги. Герої не вмирають» Ахтема Сейтаблаєва, «Донбас» Сергія Лозніци, «Додому» Нарімана Алієва, "Атлантида» Валентина Васяновича, «Погані дороги» Наталки Ворожбит i велика кількість документальних стрічок, серед яких слід відзначити «Рідні» Віталія Манського й «Земля блакитна як апельсин» Ірини Цілик - усі ці кінотвори було здійснено за частково державні кошти протягом 2017-2020 років. Деякі з перелічених фільмів отримали високі відзнаки на всесвітньо відомих кінофестивалях, зокрема «Погані дорогі» й «Атлантида» здобули премії на Венеціанському кінофестивалі. Слід віддати належне режисерам і сценаристам зазначених кінокартин, вони не оспівували велич війни, натомість намагалися донести до глядача всі їі жахіття та марність, протиставляли вартість людського життя нищівній машині війни.

Проте іншою, більш глибинною, на нашу думку, формою причетності й співпереживання людським трагедіям і долям є театр. Театральне мистецтво не має аналогів в інших видах мистецтва, оскільки від самого початку свого існування театр апелював до ритуалів та обрядів, пов'язаних 3 архетипними моментами життя суспільства. Сакральність дії полягала в тому, що всі, включно з глядачами, ставали учасниками драми, що розгорталася.

Важливим моментом є те, що уявлення, присвячені війні, з'явилися одночасно з народженням театру з обрядового культу, оскільки формування уявлень зумовлювалося необхідністю мати в першооснові якусь певну подію, яка мала конфліктний характер. Деякі дослідники, зокрема Е. Шафіi, вважають, що саме війна заставила людей створити театр і показати свої та чужі пригоди в ході боротьби з природними явищами чи богами. Саме тому дослідники світового театру присвячують перші сторінки своїх праць п’єсам про стародавні війни [9, с. 103].

Античний i середньовічний театри змальовували політичне життя тогочасного соціуму, формували так звані «документи епохи», з яких ми можемо здобувати знання про суспільно- політичні драми, які відбувалися в той історичний період. Пізніше Д. Дідро й Жћ.-Жћ. Руссо відзначали виховний та єднальний вплив театру античності на народ і закликали до створення Народного театру. Цей Народний театр стане у Франції 18-20 століть частиною ідеології, яка слугувала центром поширення певного бачення світу, передбачала певну систему цінностей, стверджувала певний порядок. Мало того, «Народний театр» у своїх успішних втіленнях на практиці не обмежувався ані національною тематикою драматургії, ані офіційною ідеологією, але й сприяв формуванню єдиного культурного простору [10, с. 106].

В Україні з розпадом Радянського Союзу не відбулося значного прориву в театральному просторі, як це сталося в деяких інших країнах, що позбулися імперських тенет (Латвія, Литва, Естонія). Автори аналітично-соціологічного дослідження «Український театр: шлях до себе» під редакцією С.Г. Васільєва [11] констатують, що в 90-х роках минулого й 10-х теперішнього століття український театр переважно залишався під впливом російської культури. Вистав, поставлених за п'єсами сучасних українських авторів, майже не існувало. Держава втратила інтерес до театру, оскільки демократія та відсутність «залізної завіси» дозволила не розглядати театр як інструмент і впливовий рушій ідеології - для цього використовувались засоби масової інформації. Театр 90-х років перестав пропонувати суспільству глибокі філософські чи політичні теми - політики було досить на телевізійних рейтингових токшоу, в країні відбувалася економічна криза, тому в театри публіку «заманювали» на легкі комедії з невишуканим вульгарним гумором.

У першій декаді 2000-х років українські театри були представлені національною хрестоматійною класикою або західними комедіями й мелодрамами. Рідкісні виключення складають вистави за п'єсами О. Ірванця (які недовго проіснували в українському театрі), «Московіада» Ю. Андруховича, «Щасливе Різдво» С. Жадана.

Події Помаранчевої революції не були осмислені в п'єсах українських драматургів і не викликали в театрах будь-якої реакції. Напередодні Революції Гідності в Театрі ім. Івана Франка відбулася вистава за п’єсою Н. Ворожбит «Квітка Будяк» (парафраз твору П. Куліша «Маклена Граса») - iї критики вважають передбаченням подій на Майдані 2014 року [11, с. 14]. (За сюжетом, по різні сторони барикад опинялися члени однієї родини). Головною театральною подією, що викладала феномен Майдану, став текст «Щоденники Майдану», який був упорядкований вище згаданою Н. Ворожбит на основі вербатіма, зібраного волонтерською групою українських режисерів, драматургів та акторів в учасників революційних подій впродовж листопада-грудня 2014 року. 
Текст був поставлений на малій сцені театру Івана Франка режисером Андрієм Маєм.

Хвиля «Нова драма» не набула поширення у 2000-х роках. М. Курочкін, Н. Ворожбит, Г. Яблонська - яскраві її представники - ширше були представлені в Росії, ніж на батьківщині. Проте пізніше, в другій декаді 20 століття цей вид драматургії почав набирати обертів у формі вербатіму, який як самостійне театральне явище з'явився у Великобританії ще у 80-х роках. Вербатім i «Нова драма» тісно пов'язані між собою. Детальніше про технологію вербатім описали у своїй монографії У. Хамонд і Д. Стюарт [12]. Цю технологію активно почали використовувати й українські драматурги як в документальних п’єсах, так і в художніх у вигляді діалогів персонажів. На думку М.А. Гоманюка, у вербатімі органічно перетинаються мистецтво й наука, що разом дає несподіваний соціальний ефект документальне викладення проблеми в живому театральному форматі, така собі журнальна стаття або навіть журналістське розслідування на сцені [13, с. 20].

Слід зауважити, що деякі документальні вистави, створені й втілені в межах українського театрального простору, набули все ж таки свого резонансу як в Україні, так і за її межами. Серед них варто відзначити текст "Моя Миколаївка» драматургині Наталки Ворожбит i режисера Георга ЖЖено. Зазначений проєкт був створений на основі розповідей дітей із невеликого села Донецької області, що ділилися своїми історіями про війну. Вистава пройшла в багатьох містах України, зокрема у Львові, Києві, Сєвєродонецьку тощо, де діти (як головні актори й носії вербатіму) змогли поділитися своїм травматичним досвідом із глядачем. Завдяки цій виставі люди 3 різних регіонів України отримали змогу збагнути те, що відчувають діти, які проживають у зоні, близької до військової, відчути причетність і співпереживання та, як наслідок, катарсис і неможливість жити за попередніми уявленнями щодо подій на Сході. Варто наголосити, що вистава «Моя Миколаївка» проходила в межах фестивалю «Донкульт» у жовтні 2014 року у Львові, що відбувався паралельно 3 хвилею внутрішнього переміщення вимушених біженців зі Сходу. Така подія мала на меті сприяти полегшенню соціальної адаптації переселенців у нових реаліях, а також створити сприятливий грунт серед місцевих мешканців, аби ця адаптація відбулася в найбільш толерантних умовах.

За останні 6 років в Україні було написано чимало п’єс про ситуацію на Сході України. Серед них варто відзначити «Саша, винеси сміття» та «Погані дороги» (Наталка Ворожбит), «ПГТ» i «Мої родичі та інші покидьки» (Лєна Лягушонкова), «Крізь шкіру» (Наталія Блок), «Лабрадор»
(Віталій Ченський), «Назву не пам'ятаю» (Катерина Пенькова), “Timetraveller's guide to Donbas" (Анастасія Косодій), «Ополченці» (Дан та Яна Гуменні), «Лисиця темна як світла ніч» (Андрій Бондаренко), «Саньок» (Оксана Гриценко), «Кімната батька» (Оксана Савченко) й багато інших. Війна в цих текстах показана не через героїзм військових на першій лінії фронту, а через маленьких побутових героїв - людей, що виживають в зоні, наближеній до бойових дій, або вимушених переселенців, які долають (або не долають) кризу ідентичності, укоріненості. Переживають трагедію війни без військових дій, шукають миру у своїй душі через відчай, біль і втрати. Лише декілька із цих текстів (шість) було поставлено на майданчиках вітчизняних театрів, що звісно $є$ недостатнім не лише в межах країни, але й навіть у межах регіонального, локального простору.

Нинішне суспільно-політичне життя, яке характеризується високою мінливістю, робить завдання побудови нової парадигми цінностей майже неможливим. Поширення аномалій і поведінки, що відхиляється від норми, створюе нові форми нормальності, яка теж має ознаки швидкої мінливості й, відповідно, робить надзвичайно складною суспільну адаптацію до змін, які відбуваються. Тому необхідність залучення мистецького потенціалу, який, на нашу думку, є важливим чинником у запобіганні ризиків, що постали внаслідок територіальної дезінтеграції країни на тлі військового конфлікту на Сході України, видається надзвичайно важливим. 3 огляду на це, вважаємо доцільним здійснення певних кроків, які могли б зупинити реальну перспективу виникнення контрідентичностей в українському суспільстві й сприяли б виходу на шлях цілісності, єдності й соборності.

Насамперед йдеться про:

- збільшення кількості постановок текстів сучасних драматургів, в яких йдеться про осмислення військового конфлікту на Сході України у вітчизняних державних і недержавних театрах;

- проведення драматургічних фестивалів на зазначену тему. В Україні вже існує низка фестивалів, які мають на меті презентувати українську нову драму, які, щоправда, проводяться нерегулярно й без широкого представлення для глядача, що робить їх явищем суто камерним, зокрема «Тиждень актуальної п'єси», "Drama UA”, «Запорізька нова драма» й інші;

- активізування творчого потенціалу сучасних українських драматургів шляхом проведення освітньо-культурних заходів: лабораторій, тренінгів, майстер-класів, орієнтованих на підвищення якості драматургічних текстів, відповідності їх сучасній театральній мові й викликам світового театру. Слід зазначити, що такі заходи існують, проте в невеликій кількості й, з огляду на 
недостатнє фінансування, нерегулярно, зокрема «Майстерня молодого. Драматург», «Лабораторія драматургії НСТДУ , Черкаська театральна лабораторія, «Клас Акт «Схід-Захід», «Школа швидкої драми Post play teatr», «Театр переселенця»;

- залучення до участі в театральному «обговоренні» теми війни директорів театрів, художніх керівників і театральних режисерів, завлітів, театральних спілок і мистецьких об'єднань;

- залучення перекладачів іноземних мов для перекладів драматургічних текстів про ситуацію на Сході України з метою їх презентації на міжнародних драматургічних фестивалях.

Уважаємо, що ці кроки сприятимуть здійсненню державної політики щодо консолідації українського суспільства в контексті національного примирення та пошуку національної ідеї.

\section{Jimepamypa}

1. Апчел O.A. Вплив елементів «Театру. Doc» на сучасний театр масових дій. Культура та інфорлаиійне суспільство XXI століття : матеріали всеукр. наук.-теорет. конф. молодих учених, м. Харків, 24-25 квітня 2008 р. Харків : ХДАК, 2008. С. 204-205.

2. Апчел О.А. Документальний театр у театральній культурі пострадянського простору, зокрема сучасної України. Культура України : Збірник наукових праць Харківської державної академії культури. 2011. Вип. 33. С. 213-222.

3. Апчел О.А. Використання елементів документального театру на шляху до формування соціально-національної самоідентифікації. Культура та інфорлаиійне суспільство XXI століття : матеріали всеукр. наук.-теорет. конф. молодих учених, м. Харків, 19-20 квітня 2012 р. Харків : ХДАК, 2012. С. 237.

4. Гоманюк Н.А. Внешнее расширение социальной группы посредством документальных жанров. Маргиналии-2015: границы культуры и текста : междунар. конф., г. Полоцк, 27-30 августа 2015 г. URL: http://uni-persona.srcc.msu.ru/site/conf/marginalii-2015/ thesis.htm (дата звернення: 25.01.2021).

5. Гоманюк Н.А. Социологический потенциал вербатим-театра. Методологія, теорія та практика соціологічного аналізу сучасного суспільства : збірник наукових праць ХНУ ім. В.Н. Каразіна. 2012. Т. 1. C. $69-82$.

6. Гоманюк М.А. Проєкт «Демократія дослівно»: від соціологічних досліджень до громадських слухань у театральному форматі. Ученые записки Таврического национального университета ил. В.И.Вернадского. 2013. Том 26 (65). № 5. С. 141-147.

7. Андрущенко П.В. Идеологическая эффективность культуры. Киев, 1988. 188 с.

8. Семенова Ю.А. Криза ідентичності в умовах трансформації системи цінностей. Гуланітарний часо nuc. 2004. № 1. С. 96-103.

9. Шафии Э. Пьеса о войне и ее виды. Общественные и гуланитарные науки : Журнал Известия Российского государственного педагогического университета ил. А. И. Гериена. URL: https://cyberleninka.ru/article/n/ piesa-o-voyne-i-ee-vidy/viewer (дата звернення: 25.01.2021).
10.Садыхова Л.Г. «Народный» театр как программа Сплочения нации. Известия вузов. Серия «Гуманитарные науки». URL: https://www.isuct.ru/ e-publ/gum/sites/ru.e-publ.gum/files/2015/to6n02/ humscience_2015_t06n02-106.pdf (дата звернення: 25.01.2021).

11.Васільєв С.Г., Чужинова I.Ю., Тукалевська 0.0. Український театр: шлях до себе. Здобутки. Виклики. Проблеми. Аналітично-соціологічне дослідження. Київ, 2009. 145 с. URL: http://nstdu.com.ua/ wp-content/uploads/2019/02/Doslidjennya_UKR_ PDF_Final.pdf (дата звернення: 25.01.2021).

12. Hammond W., Stewart D. Verbatim Theatre Techniques In Contemporary Documentary Theatre. UK : Oberon Books. 2008. 195 p.

13. Гоманюк M.А. Урбаністичний напрям у сучасному українському документальному театрі. Наукові записки Херсонського відділу Українського географічного товариства : Збірник наукових праць. 2014. Вип. 6. С. 19-22.

\section{Анотація}

Харченко Л. В. Важливість відображення конфлікту на сході України в сучасній українській драматургії: національний і локальний рівень усвідомлення проблеми. - Стаття.

У статті розглядається проблема відбиття конфлікту на Сході України в текстах сучасних українських драматургів, а також важливість презентації цих текстів на майданчиках вітчизняних і закордонних театрів. Наголошується на необхідності викладення проблем війни, що відбувається в нашій країні, з боку політичного, ідеологічного, культурного й психологічного розуміння трагедії людини, чиє життя тою чи іншою мірою було зруйноване військовим конфліктом на Сході, саме у формі театрального мистецтва. На думку авторки, така форма є найбільш архетипною та, отже, дає можливість на найбільш глибинному рівні усвідомити й сформувати власну внутрішню причетність громадян України до спільного бачення національної трагедії. Наголошується, що театр, який у нашій державі не досить оцінений iз боку формування морального, етичного й політичного виховання, містить величезний потенціал засобів художнього узагальнення, виразності й дії на масового глядача, який би зміг сприяти подоланню загроз укорінення «патології» суспільного мислення про те, що війна - це нормальний суспільний стан, з яким можна співіснувати. Підкреслено, що засоби масової інформації як четверта влада вже неспроможні чинити злам стереотипів і здійснювати переоцінку системи цінностей, а такий стан може спричинити карбування «нормальності» вбивств як на війні, так і в мирний час за національними, релігійними й іншими принципами, призвести до незворотних ментальних трансформаційних змін в українському суспільстві. Зауважується, що в глобалізаційний час, коли чітка ідеологія відсутня та кожен формує своє власне бачення політичних і морально-етичних норм, на відміну від засобів масової інформації (які втратили довіру глядача) роль театру може бути тим важливим чинником, який допоможе обивателям 
сформувати власне адекватне й правдиве бачення щодо ситуації на Сході України.

Ключові слова: сучасна українська драматургія, конфлікт на Сході України, політичний театр, стереотип, ритуал, драматургічний текст, національна ідея, причетність, ідентичність.

\section{Summary}

Kharchenko $L . V$. The importance of reflecting the conflict in the Eastern Ukraine in contemporary Ukrainian drama: the national and local level of realising problems. - Article.

The article considers the problem of reflecting the conflict in the Eastern Ukraine in the texts of modern Ukrainian playwrights, as well as the importance of presenting these texts on the platforms of domestic and foreign theaters. It emphasizes the need to cover the problems of the war in our country in terms of political, ideological, cultural and psychological understanding of the tragedy of a person whose life was destroyed by the military conflict in the East, using the form of theatrical art. According to the author, this form is the most archetypal and, therefore, provides an opportunity to realize and form at the deepest level the internal involvement of the citizens of Ukraine in the common vision of the national tragedy. It is emphasized that the theater, which in our country is insufficiently valued in terms of the formation of moral, ethical and political education, has a huge potential for artistic generalization, expressiveness and impact on the mass audience, which could help overcome the threats of "pathology" of public thinking that war is a normal social state to coexist with. It is highlited that the media, as the fourth power, is no longer able to break stereotypes and re-evaluate the value system, and such a state can lead to the minting of "normal" killings both in war and in peace on national, religious and other principles and can lead to irreversible mental transformational changes in Ukrainian society. It is noted that under globalization, when there is no clear ideology and everyone forms their own vision of political and moral and ethical norms, in contrast to the media (which have lost the trust of the audience), the role of theater can be an important factor in helping citizens form their own adequate and a true vision of the situation in the Eastern Ukraine.

Key words: modern Ukrainian drama, the conflict in the Eastern Ukraine, political theatre, stereotype, ritual, dramatic text, national idea, complicity, identity. 